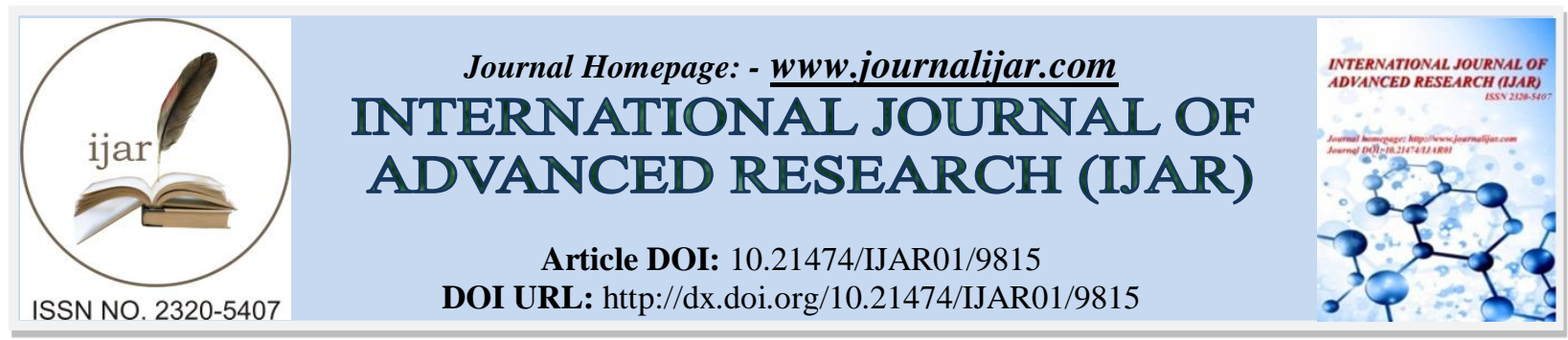

RESEARCH ARTICLE

\title{
ANTIBACTERIAL ACTIVITY OF VARIOUS OILS AND ETHANOL EXTRACT PROPOLIS AGAINST GRAM POSITIVE AND GRAM NEGATIVE BACTERIA.
}

\author{
Vildana Hadžić $^{1}$, Anesa Jerković Mujkić ${ }^{2}$, Darja Husejnagić ${ }^{3}$ and Azra Bačić ${ }^{4}$. \\ 1. Hospital for Respiratory diseases and TBC, 72270 Travnik, Bosnia and Herzegovina. \\ 2. University of Sarajevo, Faculty of Science, 71000Sarajevo, Bosnia and Herzegovina. \\ 3. University of Tuzla, Faculty of Science, 75000Tuzla, Bosnia and Herzegovina. \\ 4. Institute for Biomedical Research and Diagnostic, 72270 Travnik, Bosnia and Herzegovina.
}

\section{Manuscript Info}

(..........................

Manuscript History

Received: 04 August 2019

Final Accepted: 06 September 2019

Published: October 2019

Key words:-

Antibacterial activity, Cocos nucifera,

Nigella sativa, Olea europea, Propolis.

\section{Abstract}

For many years, medicinal plants and other natural products have been used as traditional treatments for numerous human infections and as food preservatives. Natural products are chemical compounds or substances produced by a living organism, or found in nature; that have pharmacological or biological activity. Propolis is a natural resinous substance collected by honeybees from parts of plants, buds, and exudates, mixed with bees wax and salivary enzymes. Different biological properties have been attributed to propolis, but probably one of the most important properties is antibacterial activity. The oil of the Nigella sativa is used for many diseases and also use as food preservative, condiment, carminative, analgesic in every parts of world. The oil from the coconut tree has various biological effects; strong antibacterial activity is one of them. Among the benefits that the consumption of olive oil can exert on human health, its antibacterial activity emerges as a promising new property. The antibacterial activities of these natural products were tested in this study against the Gram positive and Gram negative reference bacterial strains: Staphylococcus aureus, Rhodococcus equi, Salmonella enterica and Listeria monocytogenes, using the Kirby Bauer well diffusion method. Observation of the study was that propoils posses strong antibacterial potential against Gram positive pathogenic bacteria Staphylococcus aureus and Rhodococcus equi, but didn't have any effect on Gram negative bacteria. Essential oil from Nigella sativa also showed pronounced activity against Staphylococcus aureus, and it was less effective on Gram negative bacteria. Gram positive pathogens were more sensitive to the effect of the coconut and olive oil as well.

Copy Right, IJAR, 2019,. All rights reserved.

\section{Introduction:-}

Over the last several years, a worldwide trend has been observed in the use of natural products, on various infections treatment, due to their proven-by-evidence pharmacological effect. Propolis is a natural resinous substance collected by honeybees from parts of plants, buds, and exudates, mixed with bees wax and salivary enzymes. Propolis is mainly constituted by resin (50\%), wax (30\%), essential oils (10\%), pollen (5\%), and other substances (5\%), such as 
debris, minerals and organic compounds. Polyphenols, terpenoids including steroids, naphthalene and stilbene derivatives, and fatty acids are some examples of organic compounds that can be found in propolis (Burdock, 1998). The chemical composition of propolis is highly variable and depends on the local flora at the site of collection and on the season of collection. Despite potential intrinsic differences, which may depend on the origin, it has been proven that most propolis variants have a wide range of biological therapeutic effects, such as antibacterial, antifungal and antiviral activity(Toreti, et.al., 2013; Banskota, et.al., 2001).

One of the first biological activities to be recognized and probably one of the most important properties of propolis is the antibacterial activity, especially against bacteria. Several studies have been performed to evaluate this property against a large panel of Gram-positive and Gram-negative bacteria(Fokt et al., 2010).

Propolis affects cytoplasmic membrane, inhibits bacterial motility and enzyme activity, exhibits bacteriostatic activity against different bacterial genera and can be bactericidal in high concentrations (Mirzoeva et al., 1997).

Black cumin (N. sativa) seeds have been used traditionally in Middle Eastern folk medicine as a treatment for various diseases for more than 2000 years ago (Phillips, 1992).

Black cumin has been traditionally used in the Arabian countries, Indian continent and Europe for culinary and medicinal purposes as a natural remedy for a number of illnesses and conditions that include asthma, hypertension, diabetes, inflammation, cough, bronchitis, headache, eczema, fever, dizziness and influenza. The seeds or its oil are used as a carminative, diuretic, lactagogueand vermifuge (Ali \& Blunden, 2003). The seeds of Nigella sativa are composed of more than 100 compounds. N sativa seeds contain 36\%-38\% fixed oils, proteins, alkaloids, saponin and $0.4 \%-2.5 \%$ essential oil (Salih et al., 2009). The oil of the Nigella sativa is used for many diseases and also use as food preservative, condiment, carminative, analgesic in every part of world (Salem, 2005). Huge number of studies has been carried out in recent years on the pharmacological effects of these seeds and also the possible relationship with their constituents. A number of these investigations emphasized the antibacterial effect of them by using different extracts. Cocos nucifera L. is commonly called the "coconut tree" and is the most naturally widespread fruit plant on Earth. The plant is mainly used as a staple food crop, and a source of wood and handicrafts, among many other uses, and is thought by many to be the world's most useful plant and medicinal plant in tropical and subtropical countries. Throughout history, humans have used C. nucifera L. as medicinal plant in therapeutical purposes (Lima et.al., 2015). The constituents of coconut oil have various biological effects, such as antihelminthic, antiinflammatory, antinociceptive, antioxidant, antifungal, antibacterial, and antitumor activities. This activity was attributed mainly to the high content of phenolic compounds (Borate, et.al., 2013). Some of the most promising research in recent years has been in the area of using lauric acid or monolaurin, both derived from coconut oil, in treatments for antibiotic resistant bacteria. Olive tree (Olea europea L.) grows in tropical and subtropical regions and it has been used for medical purposes since many years ago (Visioli et al., 2005).

Olive oil and olive leaf extracts have been employed in folk medicine for centuries. This oil contains phenolic and polyphenolic compounds such as oleuropein and hydroxytyrosol that eliminate free radicals, and it is known to have antibacterial, anti-inflammatory and antioxidant activity (Amani et al., 2015). It is well-demonstrated that olives and their derived products, especially olive oil, possess compounds with antibacterial activity.

The bactericidal activity of many different types of olive oils against several microorganisms has been studied in vitro.

Early in vitro studies showed that several polyphenols in olive oil have antibacterial properties against human pathogens, particularly oleuropein, tyrosol, and hydroxytyrosol (Medina, et. al., 2006).

\section{Material And Methods:-}

For this study commercially available ethanol extract of propolis (EEP) (Medex) Black cumin oil (Nigella sativa L.) (Porta Naturae), Olive oil (Olea europea L.) (Basso) and Coconut oil (Cocos nucifera L.) (Ga Me Ha, Sarajevo) were used. Samples were stored at room temperature, and analysed immediately after opening.

\section{Bacterial strains:-}

In this study four different referent bacterial strains were used: Staphylococcus aureus ATCC 25923, Rhodococcus equi ATCC 6939, Salmonella enterica ATCC 14028 and Listeria monocytogenes ATCC 19111. Stock culture each 
of the tested bacteria was stored at $-70{ }^{\circ} \mathrm{C}$ and was retrieved by subculturing on selective media (Biolife, Italy) described in Table 1. Three pure colonies of the same morphological type were selected from agar plates and aseptically transferred into test tubes containing $10 \mathrm{~mL}$ of Mueller-Hinton broth (Biolife, Italy) using a sterile loop. The culture tubes were then incubated at $37^{\circ} \mathrm{C}$ for 24 hours to obtain fresh cultures.

Table 1:- Referent bacterial strains (Liofilchem, Italy) and selective culture media used for the research

\begin{tabular}{|c|c|c|c|c|c|}
\hline Bacterial strains & \multicolumn{2}{|c|}{ Culture media } & $\begin{array}{c}\text { Temperature } \\
\text { of incubation } \\
\left({ }^{\circ} \mathbf{C}\right)\end{array}$ & $\begin{array}{c}\text { Duration of } \\
\text { incubation } \\
\text { (h) }\end{array}$ & $\begin{array}{c}\text { Aerobic/anaerobic } \\
\text { conditions of growth }\end{array}$ \\
\hline $\begin{array}{c}\text { Staphylococcus } \\
\text { aureus ATCC } \\
25923\end{array}$ & $\begin{array}{c}\text { Baird Parker } \\
\text { agar } \\
\text { Salt manitol } \\
\text { agar }\end{array}$ & $\begin{array}{c}2-3 \text { mm yellow } \\
\text { colonies }\end{array}$ & 37 & 24 & Aerobic \\
\hline $\begin{array}{c}\text { Salmonella } \\
\text { eneterica ATCC } \\
\text { 14028 }\end{array}$ & $\begin{array}{c}\text { SS agar } \\
\text { Xylose Lysine } \\
\text { Deoxycholate } \\
\text { agar }\end{array}$ & $\begin{array}{c}2-3 \text { mm } \\
\text { transparency } \\
\text { colonies, black } \\
\text { centre }\end{array}$ & 37 & 24 & Aerobic \\
\hline $\begin{array}{c}\text { Listeria } \\
\text { monocytogenes } \\
\text { ATCC 19111 }\end{array}$ & $\begin{array}{c}\text { ALOA (Agar } \\
\text { Listeria } \\
\text { Ottavani \& } \\
\text { Agosti) }\end{array}$ & $\begin{array}{c}\text { Grey small } \\
\text { colonies }\end{array}$ & 37 & 24 & Aerobic \\
\hline $\begin{array}{c}\text { Rhodococcus equi } \\
\text { ATCC 6939 }\end{array}$ & $\begin{array}{c}\text { Brain Hearth } \\
\text { Infusion agar }\end{array}$ & $\begin{array}{c}\text { Transparency to } \\
\text { small yellow } \\
\text { colonies }\end{array}$ & 37 & 24 & Aerobic \\
\hline
\end{tabular}

\section{Assessment of Antibacterial Activity}

Antibacterial activity of propolis and oils was carried out using disc diffusion method also known as Kirby-Bauer antibacterial susceptibility test as described by Souza et al. (2005). $500 \mu \mathrm{L}$ of bacteria suspension prepared in Mueller- Hinton broth as overnight culture was adjusted to an optical density equal to 0.5 McFarland standard McFarland standard was used as a reference to adjust the turbidity of bacterial suspensions to be within the required range $-0.5 \mathrm{McFarland}$ standards is equivalent to $1.5 \times 10^{8} \mathrm{CFU} / \mathrm{mL}$ ) and uniformly spread on Petri plates ( $9 \mathrm{~cm}$ in diameter containing MHA) using a sterile L-shaped glass rod. Cylindrical wells $6 \mathrm{~mm}$ in diameter were cut into the agar with a sterile suitable device. The oils were diluted using ethylene glycol up to dilution of 1:20. The propolis was used as $10 \%$ ethanol extract stock solution and serial dilutions of ethanol extracted propolis were made using purified sterile water as a diluent. In the $6 \mathrm{~mm}$ diameter wells we homogenized together $50 \mu \mathrm{l}$ of ethylene glycol and tested oil yielding the first dilution 1:1, than 1:5, 1:10 and 1:20. Ampicilin antibiotic (Roche) discs were added as positive control. Studies were performed in triplicate. Plates are then refrigerated at $4^{\circ} \mathrm{C}$ for 2 hours to allow the propolis and oils to diffuse into the agar medium and finally incubated upside down at $37^{\circ} \mathrm{C}$ for 16 to 24 hours. The tests were conducted in triplicate and measurement of the inhibition zones was done after 16 to 24 hours. The sensitivity of individual bacteria to the oils was ranked based on the inhibition zone values expressed in millimetres $(\mathrm{mm})$ as follows: not sensitive $(-)$ for total zone diameters of $\leq 8 \mathrm{~mm}$; sensitive $(+)$ for diameters between 8 and 14 $\mathrm{mm}$; very sensitive (++) for zone diameters between 15 and $19 \mathrm{~mm}$; and extremely sensitive (+++) for zone diameters of $\geq 20 \mathrm{~mm}$ (Babu, et. al., 2011).

The bioassays were conducted in a biological safety cabinet and in accordance with the protocols of Clinical and Laboratory Standards Institute (CLSI, 2009) formerly National Committee for Clinical Laboratory Standards (NCCLS).

Table 2:-Serial dilution of tested oils and ethanol extract propolis for the assessment of antibacterial activity trough the disc diffusion method Kirby Bauer

\begin{tabular}{|c|c|c|c|c|c|c|c|c|}
\hline & \multicolumn{4}{|c|}{ Ethylen glycol } & \multicolumn{4}{c|}{ Sterile purified water } \\
\hline Dilution & $1: 1$ & $1: 5$ & $1: 10$ & $1: 20$ & $1: 1$ & $1: 5$ & $1: 10$ & $1: 20$ \\
\hline Black cumin (Nigella sativa L.) & $100: 0$ & $75: 25$ & $50: 50$ & $25: 25$ & & & & \\
\cline { 1 - 5 } Olive oil (Olea europea L.) & & & & & & & & \\
\hline Coconut oil (Cocos nucifera L.) & & & & & & & & \\
\hline
\end{tabular}




\section{Results:-}

Tables 3 and 4 summarize the results of the antibacterial activity of olive oil (Olea europea L.), coconut oil (Cocos nucifera L.), oil of black cumin (Nigella sativa L.) and $10 \%$ propolis in ethanol against the Gram positive and Gram negative bacterial strains: Staphylococcus aureus ATCC 25923 (Liofilchem, Italy), Rhodococcus equi ATCC 6939 (Liofilchem, Italy), Salmonella enterica ATCC 14028 (Liofilchem, Italy) and Listeria monocytogenes ATCC 19111 (Liofilchem, Italy) (Figure 1 and 2).

Table 3:-Antibacterial activity of various oils on Staphylococcus aureus ATCC 25923, Listeria monocytogenes ATCC 19111, Rhodococcus equi ATCC 6939

\begin{tabular}{|c|c|c|c|c|c|c|c|c|c|c|c|c|c|c|c|c|c|}
\hline \multirow{2}{*}{ 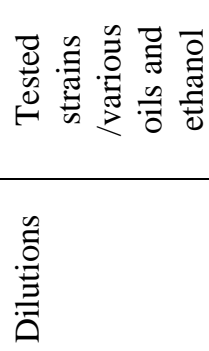 } & \multicolumn{4}{|c|}{ 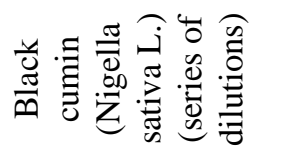 } & \multicolumn{4}{|c|}{ 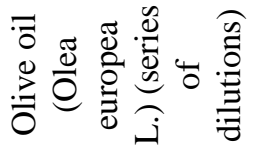 } & \multicolumn{4}{|c|}{ 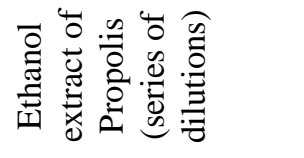 } & \multicolumn{3}{|c|}{ 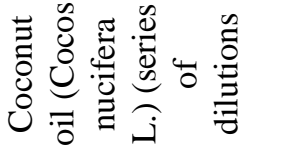 } & \multirow[t]{2}{*}{ 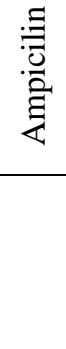 } & \multirow[t]{2}{*}{$\sum_{0}^{0}$} \\
\hline & $\ddot{-}$ & $\stackrel{n}{?}$ & $\begin{array}{l}\stackrel{0}{\ddot{ }} \\
\end{array}$ & $\stackrel{ }{\stackrel{ }{-}}$ & $\ddot{ت}$ & $\stackrel{\curvearrowleft}{?}$ & $\stackrel{\circ}{\underline{-}}$ & $\stackrel{\Omega}{\AA}$ & $\ddot{-}$ & $\stackrel{?}{?}$ & $\stackrel{0}{i}$ & 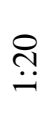 & $\underset{-}{ت}$ & 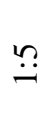 & & & \\
\hline $\begin{array}{c}\text { Staphylococc } \\
\text { us aureus } \\
\text { ATCC 25923 }\end{array}$ & $\begin{array}{c}++ \\
+\end{array}$ & $\begin{array}{c}++ \\
+\end{array}$ & $\begin{array}{l}+ \\
+\end{array}$ & $\begin{array}{l}+ \\
+\end{array}$ & + & - & - & - & $\begin{array}{c}++ \\
+\end{array}$ & $\begin{array}{c}++ \\
+\end{array}$ & $\begin{array}{l}+ \\
+\end{array}$ & $\begin{array}{l}+ \\
+\end{array}$ & $\begin{array}{l}+ \\
+\end{array}$ & $\begin{array}{c}++ \\
+\end{array}$ & - & $\begin{array}{c}++ \\
+\end{array}$ & - \\
\hline $\begin{array}{c}\text { Listeria } \\
\text { monocytogen } \\
\text { es ATCC } \\
19111\end{array}$ & - & - & - & - & $\begin{array}{l}+ \\
+\end{array}$ & $\begin{array}{l}+ \\
+\end{array}$ & - & - & - & - & - & - & - & - & 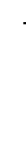 & ++ & - \\
\hline $\begin{array}{c}\text { Rhodococcus } \\
\text { equi ATCC } \\
6939\end{array}$ & - & - & - & - & - & - & - & - & + & + & + & - & - & - & 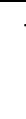 & ++ & - \\
\hline
\end{tabular}

Table 4:-Antibacterial activity of various oils on Salmonella enterica ATCC 14028

\begin{tabular}{|c|c|c|c|c|c|c|c|c|c|c|c|c|c|c|c|c|c|c|}
\hline 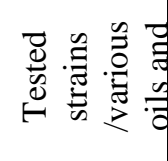 & \multicolumn{4}{|c|}{ 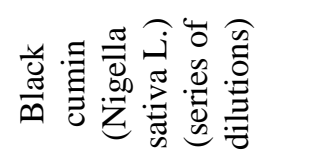 } & \multicolumn{4}{|c|}{ 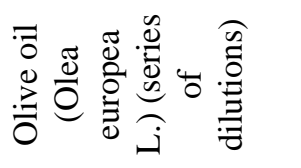 } & \multicolumn{4}{|c|}{ 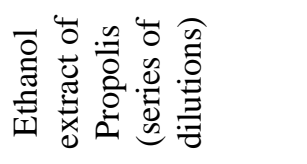 } & \multicolumn{4}{|c|}{ 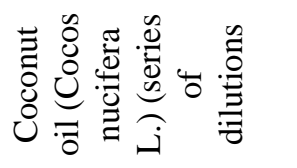 } & 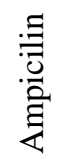 & 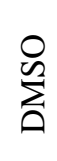 \\
\hline Dilutions & $\begin{array}{l}\text { 1: } \\
1\end{array}$ & $\begin{array}{l}\text { 1: } \\
5\end{array}$ & $\begin{array}{c}1: 1 \\
0\end{array}$ & $\begin{array}{c}1: 2 \\
0\end{array}$ & $\begin{array}{c}1: \\
1\end{array}$ & $\begin{array}{l}\text { 1: } \\
5\end{array}$ & $\begin{array}{c}1: 1 \\
0\end{array}$ & $\begin{array}{c}1: 2 \\
0\end{array}$ & $\begin{array}{c}1: \\
1\end{array}$ & $\begin{array}{l}\text { 1: } \\
5\end{array}$ & $\begin{array}{c}1: 1 \\
0\end{array}$ & $\begin{array}{c}1: 2 \\
0\end{array}$ & $\begin{array}{c}1: \\
1\end{array}$ & $\begin{array}{l}1: \\
5\end{array}$ & $\begin{array}{c}1: 1 \\
0\end{array}$ & $\begin{array}{c}1: 2 \\
0\end{array}$ & & \\
\hline $\begin{array}{c}\text { Salmonel } \\
\text { la } \\
\text { enterica } \\
\text { ATCC } \\
14028\end{array}$ & + & - & 0 & 0 & - & - & - & - & + & - & - & - & - & - & - & - & $\begin{array}{l}+ \\
+\end{array}$ & 0 \\
\hline
\end{tabular}




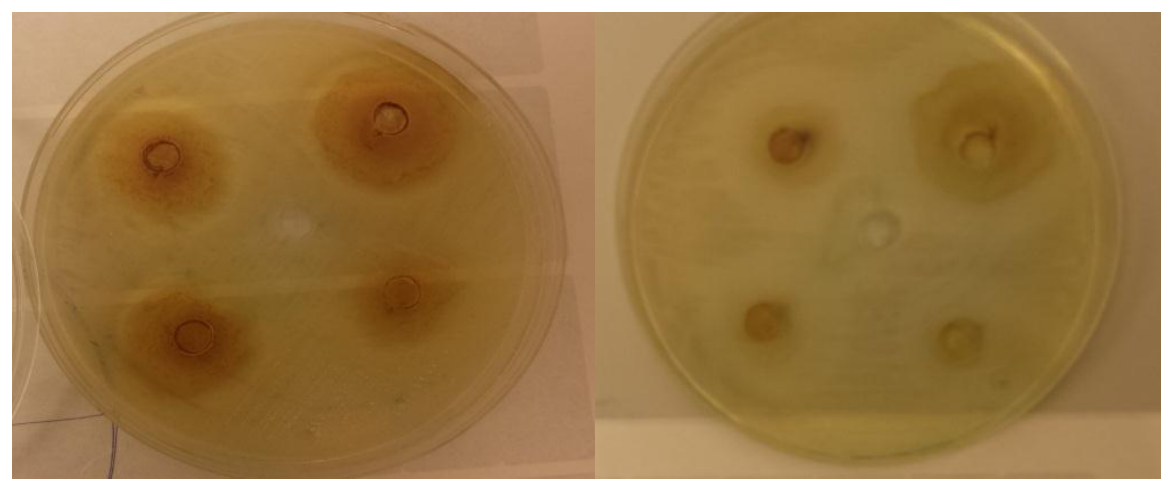

Figure 1:-Antibacterial activity of propolis on Staphylococcus aureus ATCC 25923 and Rhodococcus equi ATCC 6939

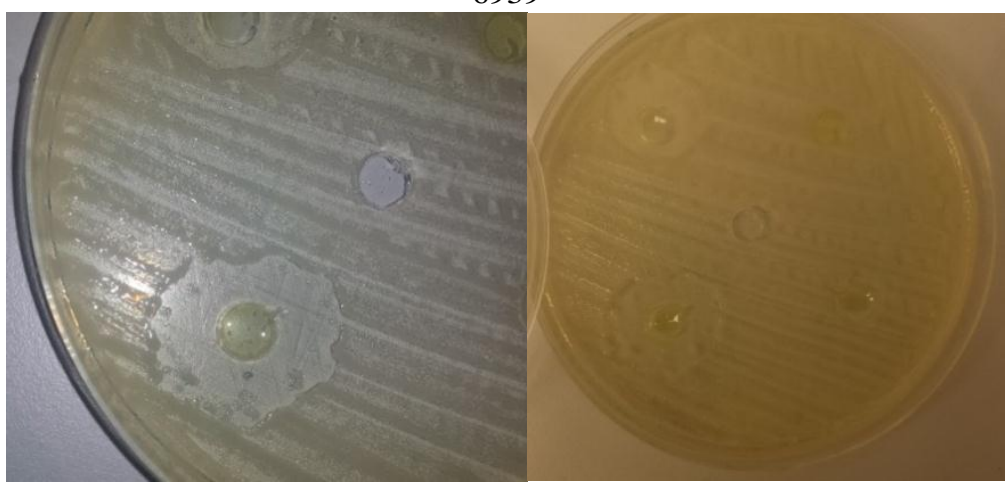

Figure 2:-Antibacterial activity of Olive oil against Staphylococcus aureus ATCC 25923 and Rhodococcus equi ATCC 6939

\section{Discussion:-}

This in vitro study demonstrated strong antibacterial activity of three commercial available oils and ethanol extract of propolis against reference Gram positive and Gram negative bacterial strains. Propolis has been used since ancient times as a remedy for the treatment of many diseases in folk medicine. Numerous in vitro studies are available on the antibacterial capacity of propolis, and therefore this study is also important for that aspect.

Ethanol extract of propolis showed the best results against Staphylococcus aureus with dilution 1:1 and 1:2. Other researches also proved strong antibacterial activity of propolis on Staphylococcus aureus including the MRSA strain (Grange, 1990). Study of Motior Rahman et al. (2010) demonstrated that propolis inhibited the Gram positive bacteria better than Gram negative, which is also in correlation with results of our study where propolis also inhibited the growth of Rhodococcus equi at dilution 1:5 and 1:10. Data from numerous studies concerning antibacterial properties of propolis support the fact that propolis is active mainly against Gram-positive bacteria and either displays much lower activity against the Gram-negative ones or is inactive at all. In our research propolis showed very weak activity against Gram negative bacteria, in this case for Salmonella enterica. It should be also considered that many different factors can affect the antibacterial properties of propolis, like geographic origin of propolis, bee species, and chemical composition (GA et al., 1994; Bankova et al., 1998).

Nigella sativa oil has been used for medicinal purposes for centuries, especially in treatment of dermatological diseases. Essential oil of black cumin seeds contains active compounds, namely; alkaloids, saponins, tannins, terpenoids and derivatives which have as anti-microbial function. In our study we found that N. sativa oil showed pronounced activity against S. aureus (ATCC 25923). This confirms the study of Agarwal et al. (1979), who reported that the oil inhibited one strain of S. aureus even up to 1:100 dilution, the least concentration tested.

Our observation is also in accordance with the study of Halawani (2009), which reported that Nigella sativa L. oil was found to be more effective on Gram positive than Gram negative bacteria. A number of compounds derived from plants often show considerable activity against Gram positive bacteria but not against Gram negative species. Gram-negative bacteria have an effective permeability barrier, comprised of the outer membrane, which restricts the 
penetration of amphipathic compounds, and multidrug resistance pumps that extrude toxins across this barrier. It is possible that the apparent ineffectiveness of plant antibacterials is largely due to the permeability barrier.

The bactericidal activity of many different types of virgin olive oils against several microorganisms has been studied in vitro and our study confirms those from Medina et al., (2013). Such study revealed that olive oil exerted a strong bactericidal action against a broad spectrum of microorganisms, this effect being in general higher against Grampositive bacteria as compared to Gram-negative bacteria. Most of the food borne pathogens tested (Listeria monocytogenes, Staphylococcus aureus, Salmonella enteritidis subsp. enterica, Yersinia sp., and Shigella sonnei) did not survive after one hour of contact with olive oils. Studies on substances responsible for antibacterial effect of olive oil are scarce and researchers analyzed only the minor polyphenols of the oil (simple phenols), but not the secoiridoid aglycons of oleuropein and ligstroside and the lignans. Likewise, there are numerous papers describing the antibacterial activity of oleuropein (Perri et al., 1999).

Our findings also confirm that olive oil has strong antibacterial effect on Gram positive bacteria especially on the Listeria monocytogenes.

Coconut oil has been confirmed to possess antibacterial, antiviral and antiprotozoal in different studies. It has a unique role in the diet as an important physically functional food and is composed of medium chain fatty acids. It contains $92 \%$ saturated fatty acids, approximately $50 \%$ of which is lauric acid. Monolaurin and other medium chain monoglycerides are shown to have the capacity to alter microbial cell walls, penetrate and disrupt cell membranes, and inhibit enzymes involved in energy production and nutrient transfer, leading to the death of the bacteria. It is known that coconut and olive oils are traditionally used to moisturize and treat skin infections. Verallo Rowell and co-workers (2008) demonstrated that coconut and olive oil have an in vitro broad-spectrum activity against S. aureus and may be useful in proactive treatment of atopic dermatitis. This study also proved that coconut and olive oil posses strong antibacterial activity against pathogenic S. aureus in in vitro conditions, but did not have any significant effect on other tested bacterial strains.

\section{Conclusion:-}

In recent years, a large number of studies have been conducted searching the antibacterial activity of natural products. For many years, medicinal plants and other natural products have been used as traditional treatments for numerous human infections and as food preservatives. This has been proved as an abundant source of biologically active compounds, making them an effective source for combating bacterial pathogens. Disc diffusion method is a very useful tool for evaluating effectiveness of natural antibiotics. Based on the data obtained from the present study, it is concluded that Staphylococcus aureus and Rhodococcus equi were susceptible to antibacterial action of the ethanolic extract of propolis. These results have shown that EEP may hold potential as an antibacterial preservative or for the treatment of various infections caused by these pathogens.

Although the food industry primarily uses essential oils as flavourings, so they represent an interesting source of natural antibacterials for food preservation. Nigella sativa oil is a very good candidate for growth suppression of S. aureus sand Samonella enterica because they are most common as food pathogens. Coconut and olive oil also can be used as food preservatives because it can reduce number of pathogenic strains. Therefore, olive oil could be a hurdle component in certain processed foods and exert a protective effect against food borne pathogens.

\section{References:-}

1. Agarwal, R, Kharya, MD. and Shrivastava, R. (1979). Antibacterial and anthelmintic activities of the essential oil of Nigella sativa L. Indian J Exp Biol. 17(11), 1264-1265.

2. Ali, B.H., Blunden, G.(2003). Pharmacological and toxicological properties of Nigella sativa.Phytotherapy Research. Volume 17, Issue 4. April 2003, Pages 299-30.

3. Amani, R, Kariman, N., Mojab, F., Alavi, M.H., Majidi, S. (2015). Assessing comparison the effect of cooling gel pads and topical olive oil on the intensity of episiotomy pain in primiparous women. Complement Med J facult Nurs Amp. 4(4): 977-86.

4. Babu, A.J., Sundari, A. R.,Indumathi, J., Srujan, V.N., and Sravanthi, M. (2011). Study on the antibacterial activity and minimum inhibitory concentration of essential oils of spices. VeterinaryWorld. Vol. 4, no. 7, pp. 311-316. 
5. Bankova, V., Boudourova-Krasteva, G., Popov, S., Sforcin, Jm., Funari, Src. (1998). Seasonal variations of the chemical composition of Brazilian propolis. Evid Based Complement Alternat Med. 7(3): 307-315.

6. Banskota, A.H.; Tezuka, Y.; Kadota, S. (2001). Recent progress in pharmacological research of propolis. Phytother. Res., 15, 561-571

7. Borate, PP., Disale, SD., Ghalme, RS. (2013). Studies on isolation, analysis and antibacterial properties of coconut shell oil. Int J Adv Sci Technol Research. 2: 146-157.

8. Burdock, G.A. (1998).Review of the biological properties and toxicity of bee propolis (propolis). Food Chem. Toxicol., 36, 347-363.

9. Clinical and Laboratory Standards Institute. (2009) Performance Standards for Antibacterial Susceptibility Testing; Nineteenth Informational Supplement. Wayne, PA: CLSI document. M100-S19.

10. Fokt, H., Pereira, A., Ferreira, A. M., Cunha, A., and Aguiar, C.; (2010). How do bees prevent hive infections? The antibacterial properties of propolis. Current research, Technology and Education Topics in Applied Microbiology and Microbial technology, p: 481-493

11. Ga, H., Shibuya, T., Sugimoto, T., Kurimoto, M., Nakajima, S. (1994)Isolation and identification of antibacterial compounds in Brazilian propolis. Biosci. Biotechnol. Biochem.58, 945-6.

12. Grange, J M., Davey, R W. (1990). Antibacterial properties of propolis (bee glue). Journal of the Royal Society of Medicine. 83(3): 159-160.

13. Halawani, E. (2009). Antibacterial activity of thymo-quinone and thymohydroquinone of Nigella sativa L. and their interaction with some antibiotics. Adv Biol Res.3:148-152.

14. Lima, E.B.C., Sousa1, C.N.S., Menese, L.N., Ximenes, N.C., Santos, Júnior, M.A., Vasconcelos, G.S., Lima, N.B.C., Patrocínio, M.C.A., Macedo,D. and Vasconcelos, S.M.M. (2015).Cocos nucifera (L.) (Arecaceae): A phytochemical and pharmacological review. Brazilian Journal of Medical and Biological Research. 00(00): 112, ISSN 1414-431X Review.

15. Medina, E., de Castro, A., Romero, C., and Brenes, M. (2006). Comparison of the concentration of phenolic compounds in olive oils and other plant oils: correlation with antibacterial activity. J. Agric. Food Chem. 54, 4954-4961.

16. Mirzoeva, O.K., Grishanin, R.N., Colder, P.C. (1997). Antibacterial action of propolis and some of its components: the effect on growth, membrane potential and motility of bacteria. Microbiological Research.52:239-246.

17. Motiur Rahman, M., Allen Richardson, M., Sofian, A. (2010).Antibacterial activity of propolis and honey against Staphylococcus aureus and Escherichia coli. African Journal of Microbiology Research. Vol. 4(16) pp. 1872-1878, 18.

18. Perri, E., Rafaelli, A., Sindona, G. (1999). Quantification of oleuropein in virgin olive oil by ion spray mass spectrometry-selected reaction monitoring. J. Agric. Food Chem.;47:4156-4160.

19. Phillips, JD. (1992). Medicinal plants. Biologist.;39:187-191.

20. Salem, M. L. (2005). Immunomodulatory and therapeutic properties of Nigella sativa L. Seed. International Immunopharmacology. 5(13-14), 1749-1770.

21. Salih, B., Sipahi, T., Donmez, E. O. (2009). Ancient Nigella seeds from BoyaliHoyuk in North-Central Turkey. Journal Ethnopharmacol.124(3), 416-420.

22. Souza, E.L., Lima, E.O., Freire,K.R., and Sousa,C.P. (2005). Inhibitory action of some essential oils and phytochemicals on the growth of various moulds isolated from foods. Brazilian Archives of Biology and Technology. Vol. 48, no. 2, pp. 245-250.

23. Toreti, V.C.; Sato, H.H.; Pastore, G.M.; Park, Y.K. (2013). Recent progress of propolis for its biological and chemical compositions and its botanical origin. Evid. Based Complement. Altern. Med., doi:10.1155/2013/697390.

24. Verallo-Rowell,V.M., Dillague,K.M., and Syah-Tjundawan, B. S. (2008).Novel antibacterial and emollient effects of coconut and virgin olive oils in adult atopic dermatitis. Dermatitis. Vol. 19, no. 6, pp. 308-315.

25. Visioli, F., Caruso, D., Grande, S., Bosisio, R., Villa, M., Galli, G. (2005). Virgin Olive Oil Study (VOLOS): Vasoprotective potential of extra virgin olive oil in mildly dyslipidemic patients. Eur J Nutr.44(2):121-7. 